\title{
Ultralyd mot benbrudd?
}

\section{Lavintensitet pulset ultralyd har ingen effekt i behandling av tibia- frakturer, viser ny studie.}

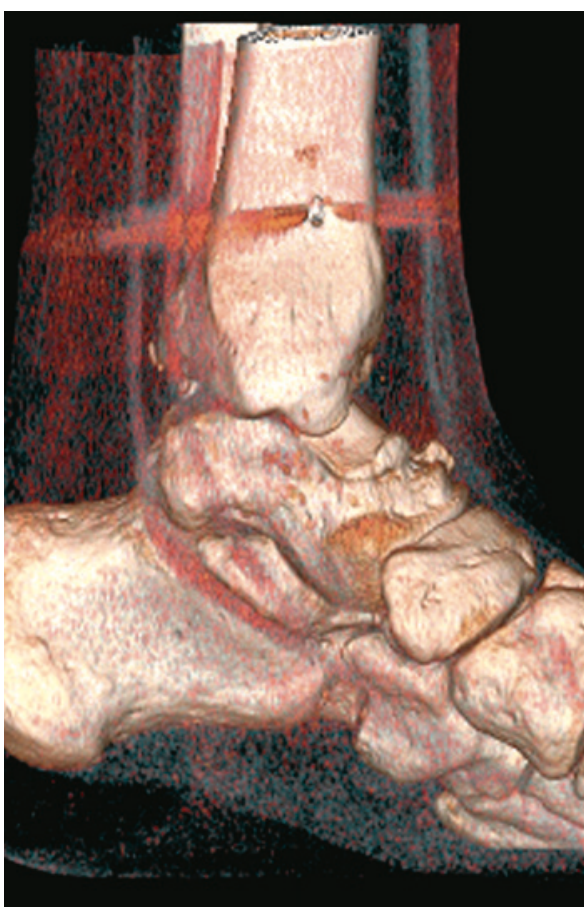

Illustrasjonsfoto: Science Photo Library
Tibiaskaftfraktur behandles vanligvis operativt med margnagling. På grunn av risiko for manglende tilheling - pseudartrose - har det vært diskutert om bruk av lavintensitet pulset ultralyd i behandlingen kan øke beintilhelingen. Slik ultralydbehandling bestråler vevet med akustiske bølger. Studiene som så langt har vært utført har imidlertid vært av lav kvalitet med usikre funn. Internasjonalt har det vokst frem en omfattende industri som tjener gode penger på slik behandling, derfor er det viktig å finne ut om det faktisk virker.

I en ny studie som nylig er publisert i $B M J$ ble drøyt 500 pasienter med tibiaskaftfraktur randomisert til hjemmebehandling med lavintensitet pulset ultralyd eller narrebehandling (1). Pasienter med åpne og lukkede tibiafrakturer som egnet seg for margnagling ble inkludert, mens blant annet pasienter med intraartikulære frakturer og spiralfrakturer ble ekskludert. Behandlingen skulle gjennomføres daglig i 20 minutter inntil frakturen hadde tilhelt eller ved avslutning av studien etter ett år.

Etter ett år var det ingen forskjell mellom gruppene på et funksjonsskåringsverktøy eller radiografisk tilheling. En firedel av pasientene oppga å ha brukt behandlingen i $50 \%$ eller mindre av anbefalt tid.

- Studien støtter inntrykket av at lavintensitet ultralydbehandling ikke har noen plass som tillegg til operativ behandling av ferske brudd, sier Gunnar B. Flugsrud, overlege ved ortopedisk klinikk ved Oslo universitetssykehus. Han påpeker at relativt dårlig pasientetterlevelse er en svakhet.

- Basalforsøk har indikert at lavintensitet pulset ultralyd kan påvirke cyklooksygenase 2 og prostaglandin E2, mens andre forsøk har målt økt celleproliferasjon, sier Flugsrud. Behandlingen har vært forsøkt som tillegg til konservativ og operativ primærbehandling av ferske brudd, ved stressfrakturer, ved osteotomier og ved forsinket pseudartrose.

- Det er ikke påvist reduksjon i pseudartrosefrekvens, men ved konservativ behandling av ferske frakturer er det $\mathrm{i}$ enkelte studier rapportert om opptil en tredel reduksjon i tid til radiologisk tilheling blant dem som tilhelet, sier han. Behandlingen har vært kommersielt tilgjengelig siden begynnelsen av 1990-årene.

- Lavintensitet pulset ultralyd regnes ikke som legemiddel og brukes i noen grad uavhengig av helsevesenet. Derfor er det viktig også å løfte frem studier som viser manglende effekt, sier han.

\section{Ketil Slagstad \\ Tidsskriftet}

Litteratur

1. Busse JW, Bhandari M, Einhorn TA et al. Re-evaluation of low intensity pulsed ultrasound in treatment of tibial fractures (TRUST): randomized clinical trial. BMJ 2016; 355: i5351.

\section{Fysioterapi etter overtråkk?}

\section{En ny studie trekker i tvil effekten av fysioterapi etter forstuinger i ankelen.}

Ankelforstuing er en vanlig skade, men det er uklart om det har noen gevinst å henvise pasientene rutinemessig til fysioterapi. Ankelligamentskader kan klassifiseres i grad 1-3 etter alvorlighetsgrad og grad av instabilitet $\mathrm{i}$ leddet. Hva er best behandling for de letteste skadene?

I en ny studie gjengitt i $B M J$ ble over 500 pasienter med ankelforstuing og grad 1-2skade randomisert til standardbehandling med og uten tillegg av veiledet fysioterapi (1). Treningsprogrammet besto av inntil syv halvtimesøkter med instruksjon om påfølgende hjemmeøvelser hvor blant annet isometrisk muskelstyrke, leddutslagsøvelser og motstandstrening med strikk ble vektlagt. Pasientene ble fulgt i seks måneder. Etter tre og seks måneder var det ingen forskjell mellom gruppene målt ved klinisk undersøkelse og $i$ henhold til et skåringsinstrument (foot and ankle outcome score - FAOS). Forfatterne påpeker at så mange som $43 \%$ og $38 \%$ i henholdsvis fysioterapi- og kontrollgruppen ikke oppnådde tilfredsstillende funksjon etter seks måneder (FAOS-skår på $\geq 450$ av 500).
- Studien viser at mange pasienter med ankelforstuinger kan behandles uten henvisning til fysioterapi, sier Martine Enger, som er ph.d.-student og overlege ved Oslo skadelegevakt, Oslo universitetssykehus.

- Dette er den hittil største randomiserte, kontrollerte studien der man undersøker effekten av fysioterapi etter ankelforstuing, sier hun. Hun understreker at studien bare omfatter lettere forstuinger, der ankelleddet er mekanisk stabilt eller kun litt løst.

- Klassifiseringen i grad 1-3 er forholdsvis subjektiv og gir ikke alltid et presist mål på graden av patofysiologi, sier hun. Dessuten ble bare én av tre pasienter som fylte inklusjonskriteriene rekruttert til studien. Det kan derfor foreligge en skjevhet $\mathrm{i}$ utvalget.

- Det er flere forhold som kan begrense relevansen for norske forhold. Det er belegg i litteraturen for å anbefale ortose også ved grad 1- og 2-skader, men i studien ble det ikke benyttet ortose eller annen immobilisering $\mathrm{i}$ behandlingen, sier hun.

- Videre var gjennomsnittlig BMI for studiedeltakerne 28, altså lett overvektig, noe jeg ikke tror er gjeldende for den norske pasientpopulasjonen som søker hjelp etter overtråkk, sier hun.

Enger fremhever at det i artikkelen i liten grad redegjøres for hva slags fysioterapi som ble gitt eller hvor mange som fikk balansetrening.

- Hos idrettsutøvere er balansetrening vist å forebygge nye forstuinger. Forfatterne fremhevet at en stor andel i begge grupper ikke oppnådde ønsket resultat etter seks måneder. Det er derfor behov for studier der man undersøker om andre behandlingsopplegg, inkludert fysioterapi, kan gi bedre resultat for undergrupper av pasienter, påpeker Enger.

\section{Ketil Slagstad \\ Tidsskriftet}

\section{Litteratur}

Brison RJ, Day AG, Pelland L et al. Effect of early supervised physiotherapy on recovery from acute ankle sprain: randomised controlled trial. BMJ 2016; 355: i5650. 